\title{
Бактериални биофилми при серозните отити
}

\author{
Д. Попова, С. Върбанова, М. Мелничаров \\ УМБАЛ "Царица Йоанна", МУ - София \\ Катедра по УНГ-болести
}

\begin{abstract}
Introduction: Ear infections (otitis media, or OM) is the most common illness in childhood. Otitis media with effusion (OME) is the most common reason children receive antimicrobials and undergo middle ear surgery. Biofilms have been shown to play a role in otitis media, sinusitis, cholesteatoma, tonsillitis, adenoiditis, and device infections. Biofilms are complex organized communities of attached bacteria embedded in an extracellular matrix that display many of the hallmarks of multicellular organisms including: small molecule intercellular communication systems; specialized phenotypes; and differentiated metabolism.

Objective: To test the hypothesis that chronic OM in children is biofilm-related

Recent findings: Understanding that many of the infections that affect structures of the ear are actually biofilm related. This is the base to develop rational strategy for treatment and prevention to the decease. The biofilm may play a major etiologic role in OME and olso the frequent complications. Biofilms provide bacteria with distinct advantages, including antimicrobial resistance and protection from host defenses.

Conclusion: Biofilm formation may be an important factor in the pathogenesis of chronic otitis media with effusion and their complication.
\end{abstract}

\section{Резюме}

Въведение: Серозният отит с една от най-често срещаните заболявания в детството. Най-честите причинители на серозния отит са Streptococcus pneumoni (SP); Haemophilus Influenzae (HI) и Moraxella catharralis (2). Използването на антибиотична терапия води до временно подобрение, а не до пълно оздравяване. Бактериалният биофилм (ББ) може да се дефинира като структурна общност от бактериални клетки, заградена от продуциран от тях полимерен матрикс.

Характерно за тях е подчертана резистентност към антибиотична терапия, поради обмяната на генетичен материал между инфекциозните причинители и наличието на полимерен матрикс около бактериалните клетки.

Нови виждания: Най-новите открития показват наличие на бактсриални биофилми при персистиращи серозни отити в средното ухо, които променят патофизиологията на това заболяване и подхода при лечението на заболяването и усложненията му.

\section{Въведение}

Серозният отит може да се дефинира като наличие на течност в средното ухо без симптоми или признаци на остра инфекция. Тези промени в състоянието на средното ухо водят до намалена подвижност на membrana tympani и свързаната с нея слухова верига и може да се разглежда като бариера на звуковата вълна. Възрастта, при която се наблюдава серозният отит, е между седеммесечна възраст и шест години, един от основните симптоми е намалението на слуха, което в тази възраст при продължително персистиране на заболяването води до променено говорно развитие.

Заболяването може да възникне спонтанно в резултат на:

- дисфункция на евстахиевата тръба;

- алергия и имунологични фактори;

- баротравма;

- след остър отит - при адхезията на бактерията върху възпаления назофаринкс, поради нарушаване на нормалния мукоцилиарен защитен механизъм на евстахиевата тръба и средното ухо.

Децата с аномалии на мекото небце, Down или Robin syndrom са предразположени към често рецидивиране на серозният отит.

Най-честите причинители на серозния отит са Streptococcus pneumoni (SP); Haemophilus Influenzae (HI) и Moraxella catharralis (2). Патофизиологичните механизми на серозния отит не са добре проучени. Използването на антибиотична терапия води до временно подобрение, а не до пълно оздравяване. При рутинно микробиологично изследване между 40-60\% от изследвания ексудат е стерилен (2). При изследване на полимеразната активност се установява метабо- 
литна активност, при прилагане на допълнителни изследвания се установява наличие на бактериален биофилм в средното ухо.

\section{Бактериалният биофилм}

Бактериалният биофилм (ББ) може да се дефинира като структурна общност от бактериални клетки, заградена от продуциран от тях полимерен матрикс $(3,4)$. ББ е закрепен за ендотела на тъпанчевата кухина, по този начин се сформира своеобразна колония с намалена консумация на кислород и хранителни вещества. Характерно за тях е подчертаната резистентност към антибиотична терапия поради обмяната на генетичен материал между инфекциозните причинители и наличието на полимерен матрикс около бактериалните клетки. Матриксът протектира клетките вътре в биофилма и спомага на взаимодействието между тях. Той е достатъчно здрав и многократно увеличава антибиотичната резистентност.

При формирането ББ бактериите се прилепват към увредената ендотелна стена. Организират се като гроздове, повлекла, гъбовидни формации, оградени са от бактериални екстрацелуларни полизахариди.

Между тях се сформират водни канали, небходими за обмяна на веществата. Основната характеристика на този комплекс е промяна на бактериалния фенотип чрез интерцелуларна комуникация между бактериите. Броят на промените в генотипа регулира стабилността на ББ. По този начин се формира високорезистентен биофилм спрямо външните въздействия, особено тези на най-често използваните антибиотици. Това е и една от причините да се смята, че голяма част от персистирщите инфекции са причинени от ББ. Екстрацелуларният полизахариден матрикс, секретиран от бактериите, пречи на проникването на антибиотичните вещества. Всеки биофилм е особено резистентен към определени за него антибиотици $(7,8)$.

При изследване на ексудата на биофилм свързаните серозни отити се открива наличието на бактериален ендотоксин, който, от една страна, намалява възможностите на макрофагите да атакуват бактериите и увеличава резистентността спрямо локалния имунен отговор на организма. От друга страна - бактериалният ендотоксин е най-честата причина за намалението на звукоприемната компонента на слуховата функция, която се изразява с комбинирано намаление на слуха при тоналната прагова аудиометрия, най-често в областта на високочестотния диапазон. Причината е директното проникване в кохлеата през двете прозорчета.

\section{Диагноза}

Най-честите методи при установяване на наличие на ББ е трасмисионната електронна микроскопия (9).

\section{Лечение}

При лечението на биофилминфекциите е необходимо да се съобразим с основните етапи (от общо 5) на формирането на биофилминфекциите:

- Интрацелуларен генетичен обмен;

- Полизахариден матрикс;

- Адхезията върху ендотела на увредената от инфекцията cavum tympani, както и върху вентилационните тръбички.

- Ниска метаболитна скорост.

\section{Антибиотици}

Антибиотичното лечение може да се приложи в началния етап при формирането на биофилм инфекцията, преди да настъпи адхезията към ендотелната повърхност. Антибиотици в голяма концентрация в интрацелуларното пространство като макролиди, кетолиди и хинолони показват сравнително добри резултати при някои форми на бактериалните биофилми на серозния отит.

\section{Кортикостероиди}

Приложението на prednisolone и dexamethazone per os могат да резорбират течността за кратко време и да ограничат възпалителния фокус.

\section{Муколитици}

- Мукоактивна молекула;

- Променя реологията на секрета (храчка, слюнка);

- Увеличава мукоцилиарния клиранс;

- Инхибира бактериалната адхезия;

- Антиоксидантен ефект.

Следователно в началото на заболяването ще намалее степента на адхезия на микроорганизмите, което, от една страна, ще доведе до по-малко възпалителни промени директно върху епитела в средното ухо, а от друга, по-голяма атакуемост на микроорганизмите от приложените антибиотици и допълнителните манипулации. С увеличаването на пространството между тях се намалява възможността за обмяна на генетичен материал и намаляване на резистентността на микроорганизмите към приложената терапия (10).

\section{Хирургическо лечение}

Този метод на лечение при персистиращия серозен отит е с най-добри резултати както по отношение 
на слуховата функция, така и на биофилм инфекцията, която е чувствителна спрямо околна сухота. Механичното нарушаване целостта на биофилма при аспирация на ексудата също допринася за намаляване на хроничната инфекция.

Съпътстващата аденотомия спомага при лечението на бактериалния биофилм инфекция поради наличие на колонии от ББ по повърхността на аденоидната вегетация.

\section{Усложнения}

В някои случаи могат да се получат усложнения след поставянето на дренажните тръбички, дължащи се на сформиране на биофилм инфекции върху самата тръбичка. Поради тази причина вентилационните тръбички не трябва да стоят по-дълго от 3-6 месеца. Най-честите усложнения са (5): оторея - при която локалната апликация на ушни капки помага; мирингосклероза - без сериозни

\section{Литература:}

1. Biofilm surface area in the pediatric nasopharynx: Chronic rhinosinusitis vs obstructive sleep apnea. [Arch Otolaryngol Head Neck Surg. 2007]

2. Allison, D. (2000). Community Structure and Co-Operation in Biofilms. Cambridge: Cambridge University Press. ISBN 0521793025.

3. Mucosal biofilm formation on middle-ear mucosa in the chinchilla model of otitis media. [JAMA. 2002] Direct evidence of bacterial biofilms in otitis media. [Laryngoscope. 2001]

4. Evidence of bacterial metabolic activity in culture-negative otitis media with effusion. [JAMA. 1998]

Molecular analysis of bacterial pathogens in otitis media with effusion. [JAMA. 1995]

5. Microbiologic findings and risk factors for antimicrobial resistance at myringotomy for tympanostomy tube placement--a prospective study of 601 children in Toronto. [Int J Pediatr Otorhinolaryngol. 20 JAMA. 2006 Jul 12; 296(2): 202-11. последствия; сегментна атрофия на тъпанчевата мембрана; ретракционни джобове по pars flacida на membrane tympani и рядко cholesteatom; трайна перфорация на membrane tympani.

При двама наши пациенти чрез електронна микроскопия сме установили наличието на бактериални биофилми върху вентилационните тръбички. Откритите бактериални причинители ca Streptococcus pneumoni (SP) и Haemophilus Influenzae (HI) на другия пациент.

\section{Заключение}

Най-новите открития показват наличие на бактериални биофилми при персистиращи серозни отити в средното ухо, които променят патофизиологията на това заболяване. Някои автори споменават за генетична предизпозиция при рецидивиращите серозни отити. Поради това се налага да се прилага адекватна диагноза и лечение.

6. High incidence of Alloiococcus otitis in otitis media with effusion. [Pediatr Infect Dis J. 1999]

7. Prevalence of bacteria in children with otitis media with effusion] [J Pediatr (Rio J). 2004]

8. Detection rates of bacteria in chronic otitis media with effusion in children. [J Korean Med Sci. 2004]

9. Bacteriological and PCR analysis of clinical material aspirated from otitis media with effusions. [Int J Pediatr Otorhinolaryngol. 2001]

10. Marev, D. Acute Otitis Media Due to Mucoid Type Streptococcus pneumoniac. „Международен бюлетин по оториноларингология“, Варна, година IV, 1, 18-20, 2008. 